\title{
Flutningstími og gæði meðferðar hjá sjúklingum með ST-hækkunar-hjartadrep á landsbyggðinni - fáir ná í kransæðavíkkun innan 120 mínútna
}

Pórir S. Sigmundsson ${ }^{1}$ æknir, Daníel Arnarson² læknanemi, Arnar Rafnsson³ læknir, Viðar Magnússon³ læknir, Gunnar Pór Gunnarsson²,5 læknir, Gestur Porgeirsson ${ }^{4}$ læknir

\section{ÁGRIP}

Inngangur: Brátt hjartadrep með ST-hækkunum (STEMI) er lífshættulegt ástand. Meðferð skal veita eins hratt og hægt er með blóðpynningarlyfjum og kransæðavíkkun innan 120 mínútna frá fyrstu samskiptum við heilbrigðisstarfsmann (FSH) en að öðrum kosti með segaleysandi meðferð ef fyrirséður flutningstími er langur. Tilgangur rannsóknarinnar var að kanna flutningstíma sjúklinga með STEMI af landsbyggðinni og hvort bráðameðferð samræmdist klínískum leiðbeiningum.

Efniviður og aðferðir: Sjúkraskrár sjúklinga með greininguna STEMI við útskrift af Landspítala á árunum 2011 og 2012 voru skoðaðar afturskyggnt. Við úrvinnslu voru notaðar aðferðir lýsandi og ályktunartölfræði. Niðurstöður: Af 112 sjúklingum sem fengu greininguna STEMI eftir flutning á Landspítala frá stað utan höfuơborgarsvæðisins voru 86 sjúklingar (77\%) greindir með hjartalínuriti strax í héraði; 42 á suðursvæði og 44 á norðursvæði Íslands. Á suðursvæði var tími frá FSH að kransæđavíkkun að miðgildi 157 mínútur. Níu sajúklingar (21\%) komust í kransæðavíkkun innan 120 mínútna en enginn fékk segaleysandi meðferð og marktækt færri blóðpynningarmeđferð med klópídógrel og enoxaparín en á norðursvæði. Á norðursvæði, par sem flutningstíminn er langur, fengu nær allir sjúklingar (96\%) sem ekki höfðu frábendingar segaleysandi lyf að miðgildi 57 mínútum eftir FSH og viðeigandi blóðpynningarmeðferð. Dánartíðni var $7 \%$ og legutími á Landspítala að miðgildi 6 dagar.

Ályktanir: Utan höfuðborgarsvæðisins er tími frá FSH að mögulegri kransæðavíkkun í langflestum tilfellum lengri en 120 mínútur. Íhuga ætti segaleysandi meðferð hjá öllum sjúklingum með STEMI utan höfuðborgarsvæðisins ef frábendingar eru ekki til staðar. Skerpa parf á leiðbeiningum á suðursvæði par sem blóðpynningarlyf eru gefin marktækt sjaldnar en á norðursvæði. Símsent hjartalínurit og beint samband við hjartalækni myndi auðvelda greiningu og flýta meðferð. Samræmd skráning í STEMIgagnagrunn á landsvísu myndi auðvelda gæðaeftirlit verulega.
Fyrirspurnir: Pórir Sigmundsson thorir.sigmundsson@ karolinska.se

Greinin barst 1. september 2015 sampykkt til birtingar 9. desember 2015

Höfundar hafa útfyllt eyðublað um hagsmunatengsl.

\section{Inngangur}

Brátt hjartadrep með ST-hækkunum (ST-segment Elevation Myocardial Infarction - STEMI) er alvarlegasta birtingarmynd bráðs kransæðaheilkennis (Acute Coronary Syndrome) og orsakast af algjörri lokun á einni eða fleiri kransæðum. Brátt hjartadrep er greint með 12-leiðslu hjartalínuriti og stefnt skal að greiningu innan 10 mínútna frá fyrstu samskiptum við heilbrigðisstarfsmann (FSH). Hröð og fumlaus meðferð er afgerandi til að takmarka skaðann í hjartavöðvanum og auka lífslíkur. ${ }^{1}$ pegar greining hefur verið staðfest skal veita meðferð tafarlaust með blóðflöguhemjandi lyfjum (acetýlsalisýlsýra og klópídógrel), blóðpynnandi lyfjum (enoxaparín/ heparín) og verkjastillingu (morfín) ef engar frábendingar eru til staðar ásamt pví að undirbúa endurflæðismeðferð til að koma á blóðflæði til hjartavöðvans að nýju. Bráð hjartapræðing með kransæðavíkkun er kjörmeðferð innan 120 mínútna frá FSH en að öðrum kosti skal gefa segaleysandi lyf, helst innan 30 mínútna frá FSH. ${ }^{2,3}$ Bráðar kransæðavíkkanir (primary percutaneous coronary intervention-PPCI) eru einungis framkvæmdar á hjartapræðingarstofu Landspítala Hringbraut, sem er opin alla virka daga frá kl. 08-16 en pess utan er starfsfólk præðingarstofu í viðbragðsstöðu fyrir útköll vegna STEMI alla daga ársins. Hjartagátt Landspítala Hringbraut er frá árinu 2010 einungis opin frá klukkan 08:00 á mánudagsmorgnum og til hádegis á föstudögum. Sjúklingar með bráð hjartavandamál eru fluttir á Landspítala í Fossvogi utan pess tíma.
Pekking á flutningstíma frá FSH að hjartagátt er pví afgerandi pegar ákvarða skal meðferð við bráðu hjartadrepi. Frá norðursvæði Íslands (mynd 1) er flutningstíminn langur (að miðgildi 3:07 klukkustundir) en prátt fyrir pað fékk aðeins tæplega helmingur sjúklinga á árunum 2007-2008 segaleysandi meðferð eins og klínískar leiðbeiningar gera ráð fyrir. ${ }^{4}$ Flutningstími hjá sjúklingum með STEMI frá öðrum svæðum Íslands utan höfuðborgarsvæðisins hefur ekki áður verið skoðaður. Markmið pessarar rannsóknar var að skoða flutningstíma og gæði meðferðar hjá sjúklingum sem fengu greininguna STEMI og voru fluttir frá stað utan höfuðborgarsvæðisins til Landspítala á árunum 2011 til 2012 en jafnframt að kanna hvort breyting hafi orðið á meðferð sjúklinga með STEMI á norðursvæði Íslands fjórum árum eftir fyrri rannsókn. ${ }^{4}$

\section{Sjúklingar og aðferðir}

Úrtak rannsóknarinnar voru allir sjúklingar með ICD10 greininguna I21.0 - I21.3, brátt hjartadrep með SThækkunum í SÖGU, sjúkraskrárkerfi Landspítala, frá 1. janúar 2011 til 31. desember 2012 sem höfðu leitað sér fyrstu hjálpar hjá heilbrigðisstarfsmanni utan höfuðborgarsvæðisins (póstnúmer 190, 230-260 og 300-902) og í kjölfarið verið fluttir á Landspítala. ${ }^{5}$ Úr sjúkraskrá á Landspítala var skráð aldur og kyn sjúklings, lífsmörk við komu, tímasetning hjartapræðingar og belg- 

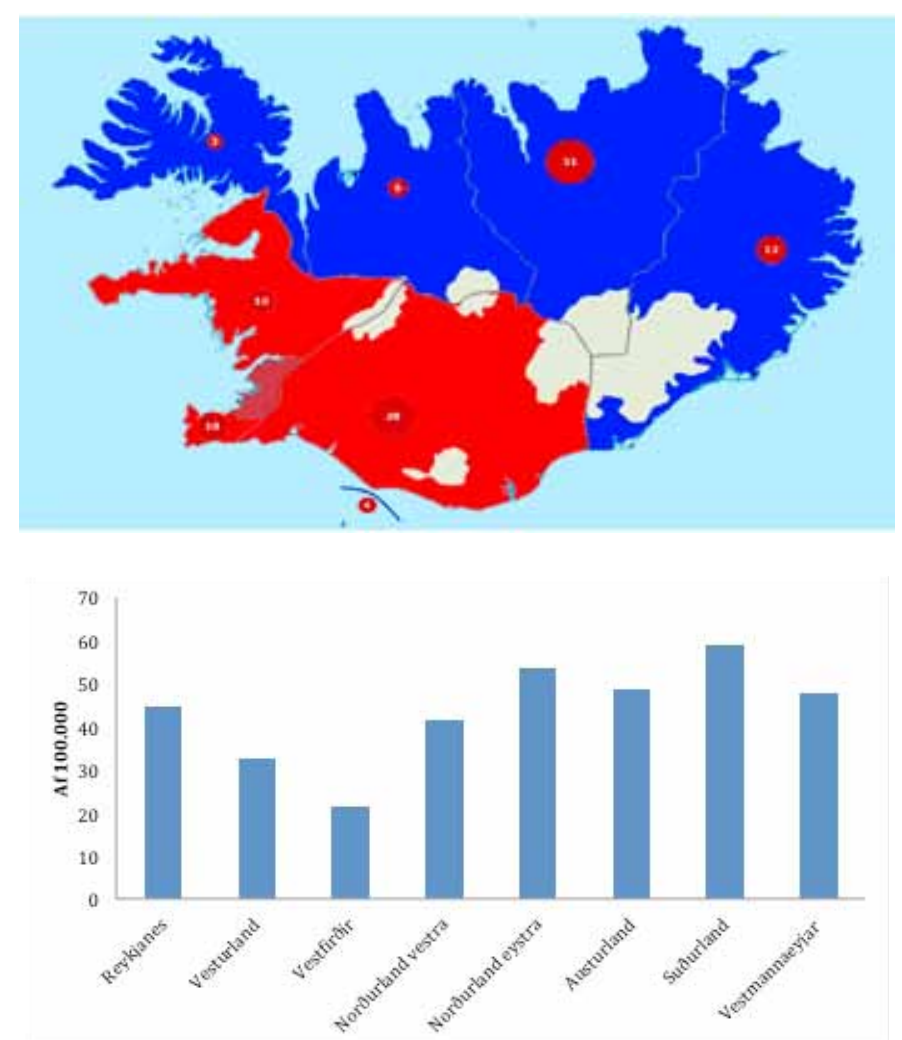

Mynd 1. Skipting landsins í norðursvæði að viðbættum Vestmannaeyjum (blátt) sem er upptökusvæði sjúkraflugvélar og suðursvæði (rautt) paðan sem sjúklingar eru yfirleitt fluttir með sjúkrabíl á Landspítala. Hringirnir sýna fjölda sjúklinga með STEMI í hverjum landshluta fyrir sig á tveggja ára tímabili (2011-2012) og stöplaritið sýnir nýgengi STEMI á hverja 100.000 íbúa eftir landshlutum.

víkkunar og hvort viðkomandi undirgekkst aðra præðingu, opna hjartaaðgerð eða lagðist inn á gjörgæslu, auk legutíma, alvarlegra fylgikvilla (svo sem heilablóðfalls og alvarlegra blæðinga sem pörfnuðust blóðgjafar) og dánartíðni innan 30 daga. Úr sjúkraskrá í héraði voru skráðar niðurstöður fyrsta hjartalínurits auk helstu tímasetninga, svo sem upphafs einkenna, FSH, fyrsta hjartalínurits og lyfjagjafar með áherslu á blóðflöguhemjandi, blóðpynnandi og segaleysandi lyf. Frá Neyðarlínu fengust upplýsingar um flutningstíma og flutningsmáta og fjölda koma á heilbrigðisstofnanir aðrar en Landspítala Hringbraut. Út frá pessum upplýsingum var heildarflutningstími (tími frá FSH að komu á Landspítala Hringbraut) reiknaður, auk tafa sem urðu á meðferð sjúklinga sem farið var með fyrst á Landspítala í Fossvogi í stað pess að flytja pá beint á præðingarstofu á Hringbraut. Við úrvinnslu gagna var landinu skipt upp í tvo hluta; norðursvæði og Vestmannaeyjar sem er upptökusvæði sjúkraflugvélar, og suðursvæði (sjá mynd 1).

Allar upplýsingar voru skráđar inn í Microsoft Excel og SPSS Statistics fyrir Windows frá IBM, útgáfa 22. Tölfræðileg úrvinnsla og myndræn framsetning var unnin í báðum forritum. Viðurkenndar tölfræðiaðferðir voru notaðar; t-test til að athuga mun á samfelldum breytum og chi-square og Fisher próf á mismunandi hópum. Líkindastuðull (p-gildi) <0,05 var talinn gefa til kynna marktækan mun milli hópa.

Rannsóknin var unnin með leyfi Persónuverndar og Vísindasiðanefndar. Leyfi til gagnaöflunar fékkst hjá lækningaforstjórum allra heilbrigðisstofnana sem höfðu haft sjúklinga með STEMI til meðferðar hjá sér.

\section{Niðurstöður}

Samtals fengu 112 sjúklingar greininguna STEMI á Landspítala eftir fyrstu samskipti við heilbrigðisstarfsmann utan höfuðborgarsvæðisins. Par af voru 83 (74\%) karlar og 29 (26\%) konur. Meðalaldur var 62,7 ár (39-87 ára) en konur voru marktækt eldri en karlar (67 ára á móti 61 árs; p=0,018). Árlegt nýgengi STEMI á landsbyggðinni var 47 tilfelli á hverja 100.000 íbúa (sjá mynd 1). Alls fengu 105 sjúklingar (94\%) brjóstverk og áttu fyrstu samskipti við heilbrigðisstarfsmann að miðgildi 81 mínútu síðar (dreifing: 38-249 mínútur). Tíminn frá FSH par til fyrsta hjartalínurit var tekið var að miðgildi 12 mínútur (dreifing: 8-29 mínútur). Sjá frekari upplýsingar í töflu I.

Áttatíu og sex sjúklingar (76,8\%) fengu greininguna STEMI strax í héraði út frá breytingum á hjartalínuriti, í sjö (6,3\%) tilvikum voru engin teikn um STEMI í upphaflegu hjartalínuriti, í $10(8,9 \%)$ tilvikum var erfitt að túlka rit og í 9 (8,0\%) tilvikum var rit ekki tekið eða fannst ekki (sjá mynd 2).

Á suðursvæði voru 54 af 56 sjúklingum fluttir með sjúkrabíl og tveir voru fluttir með pyrlu. Á norðursvæði voru 53 af 56 sjúklingum fluttir með sjúkraflugi, tveir voru fluttir með sjúkrabíl og einn var fluttur með pyrlu.

Sjúklingar með teikn um STEMI í héraði

Af peim 86 sjúklingum sem álitnir voru með STEMI í héraði fengu allir nema einn acetýlsalisýlsýru, 47 (54,7\%) fengu klópídógrel, 42 (48,8\%) enoxaparín, 10 (11,6\%) heparín og 22 (25,6\%) beta-hemla (sjá töflu II). Marktækt fleiri sjúklingar á norðursvæði fengu klópídógrel, enoxaparín og heparín heldur en sjúklingar á suðursvæði (sjá mynd 3).

Á norðursvæði fengu 97\% sjúklinga segaleysandi meðferð sem ekki höfðu frábendingu fyrir slíkri meðferð. Segaleysandi lyf var gefið að miðgildi 57 mínútum (dreifing: 10-236 mínútur)

Tafla I. Upplýsingar um sjúklinga greinda með STEMI á Landspítala eftir landsvæðum. Fjöldi einstaklinga (\%). Miðgildistími er uppgefinn i mínútum.

\begin{tabular}{lccc}
\hline & $\begin{array}{c}\text { Norðursvæði } \\
\mathrm{n}=56\end{array}$ & $\begin{array}{c}\text { Suðursvæði } \\
\mathrm{n}=56\end{array}$ & p-gildi \\
\hline Meðalaldur (dreifing) & $62(39-87)$ & $63(45-86)$ & 0,76 \\
\hline Konur & $13(23)$ & $16(29)$ & 0,67 \\
\hline Einkenni að FSH (miðgildistími) & 90 & 74 & 0,27 \\
\hline FSH að hjartalínuriti (miðgildistími) & 10 & 12 & 0,35 \\
\hline Framveggsdrep & $24(43)$ & $25(45)$ & 1,0 \\
\hline Endurlífgun ${ }^{\star}$ & $9(16)$ & $4(7)$ & 0,24 \\
\hline Ytri öndunaraðstoð (CPAP) & $3(5)$ & $5(9)$ & 0,72 \\
\hline Barkapræðing & $2(4)$ & $2(4)$ & 1,0 \\
\hline Systólískur BP $\leq 90 \mathrm{mmHg}{ }^{\star *}$ & 0 & 2 & 0,24 \\
\hline Systólískur BP > $160 \mathrm{mmHg}{ }^{\star *}$ & 3 & 8 & 0,12 \\
\hline Hjartsláttartíðni $\leq 50 \mathrm{slög/mín}{ }^{\star *}$ & 3 & 2 & 1,0 \\
\hline Hjartsláttartíðni > $110 \mathrm{slög} / \mathrm{mín}^{\star *}$ & 3 & 4 & 0,71 \\
\hline
\end{tabular}

*Fyrir komu á Landspítala Hringbraut. * ${ }^{*} V i ð$ komu á Landspítala. BP= Blóðprýstingur. 


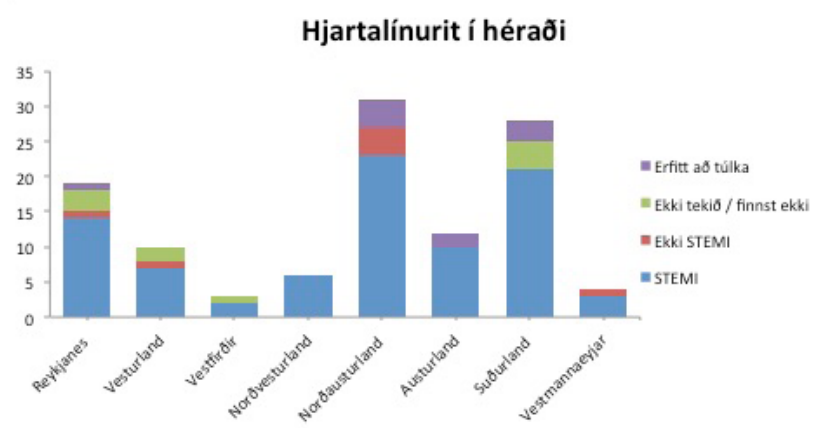

Mynd 2. Hvað sýndi hjartalínurit sem var tekið i héraði?

eftir FSH. Af peim 11 sjúklingum á norðursvæði sem höfðu frábendingu fyrir segaleysandi meðferð höfðu prír haft einkenni í of langan tíma, prír höfðu nýlega ( $<1$ viku) gengið í gegnum skurðaðgerð, prír höfðu fyrri sögu um heilablóðfall, einn talinn vera með illkynja sjúkdóm í lungum og aukna blæðingarhættu tengda pví og að lokum var einn sjúklingur talinn of gamall fyrir meðferð (áttræður). Engin frábending fannst í sjúkraskrá hjá einum sjúklingi sem ekki fékk segaleysandi meðferð. Enginn sjúklingur á suðursvæði fékk segaleysandi meðferð.

Heildarflutningstíminn frá FSH að Hjartagátt Landspítala á Hringbraut fyrir sjúklinga greinda með STEMI í héraði var skemmstur á Reykjanesi, eða að miðgildi ein klukkustund og 39 mínútur, en lengstur á Vestfjörðum og Austurlandi, um og yfir fjórar klukkustundir. Á norðursvæði var heildarflutningstíminn að miðgildi prjár klukkustundir og 13 mínútur en á suðursvæði var hann að miðgildi ein klukkustund og 44 mínútur (mynd 4).

Fjörutíu sjúklingar (95\%) frá suðursvæði og 9 frá norðursvæði gengust undir bráða kransæðapræðingu. Víkkun á kransæð tókst í 43 tilfella, par af 9 innan 120 mínútna (sjá töflu III). Í tveimur tilfellum tókst ekki að víkka kransæð, í tveimur var um útbreiddan sjúkdóm að ræða og ekki pótti fýsilegt að framkvæma víkkun og í tveimur tilfellum dó sjúklingur á præðingarborðinu áður en hægt var að víkka kransæðina. Að jafnaði liðu 42 mínútur (dreifing: 15119 mínútur) frá komu sjúklings á Hringbraut par til belgur var víkkaður.

Nítján sjúklingar voru fyrst fluttir í Fossvog, í öllum tilfellum nema einu utan opnunartíma præðingarstofu á Hringbraut. Peir gengust undir bráða kransæðapræðingu að miðgildi 44 mínútum

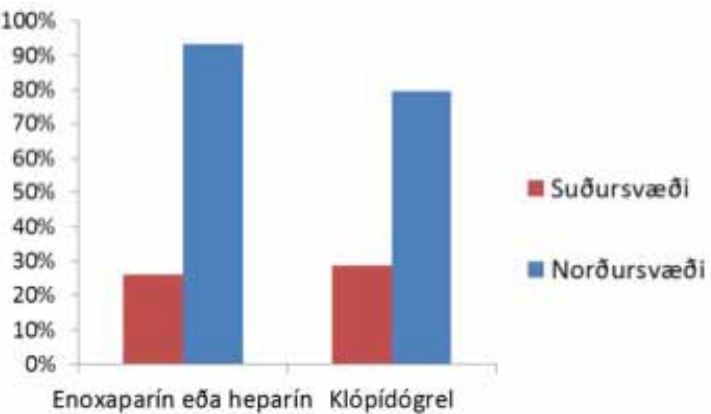

Mynd 3. Marktækur munur var á meðferð með enoxaparín/heparín og klópídógrels milli landsvæða $(p<0,001)$.

(dreifing: 10-104 mínútur) síðar og tafðist víkkun kransæðar að miðgildi um 25 mínútur borið saman við sjúklinga sem voru fluttir beint á Hringbraut. Að minnsta kosti fjórir sjúklingar til viðbótar hefðu náð í hjartapræðingu innan 120 mínútna ef peir hefðu verið fluttir beint á Hringbraut.

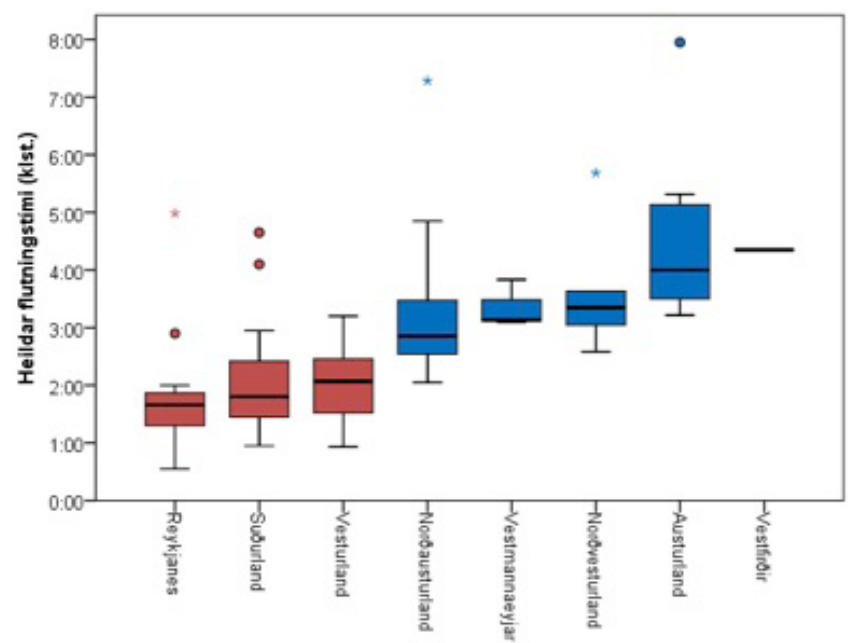

Mynd 4. Kassaritið sýnir dreifingu heildarflutningstima (FSH að Landspítala Hringbraut) frá mismunandi landshlutum. Efri mörk kassans tákna efri fjórdungamörk en neðri mörk kassans tákna neðri fjórðungamörk og lárétta línan inni i kössunum táknar miðgildi. Skeggin afmarka gildi sem teljast ekki útlagar (outliers) og deplarnir tákna útlaga en stjörnurnar tákna mikla útlaga (extreme outliers).

Tafla II. Lyfjameðferð við STEMI eftir landshlutum. Fjöldi einstaklinga (\%).

\begin{tabular}{|c|c|c|c|c|c|c|c|c|c|}
\hline Lyf & Heild & Reykjanes & Vesturland & Vestfirðir & $\begin{array}{c}\text { Norðurland } \\
\text { vestra }\end{array}$ & $\begin{array}{c}\text { Norðurland } \\
\text { eystra }\end{array}$ & Austurland & Suðurland & Vestmannaeyjar \\
\hline Acetýlsalicýlsýra & $85(98,8)$ & $14(100)$ & $7(100)$ & $2(100)$ & $6(100)$ & $23(100)$ & $10(100)$ & $20(95,2)$ & $3(100)$ \\
\hline Klópídógrel & $47(54,7)$ & $6(42,9)$ & $4(57,1)$ & $2(100)$ & $5(83,3)$ & $18(78,3)$ & $7(70)$ & $2(9,5)$ & $3(100)$ \\
\hline Enoxaparín & $42(48,8)$ & $1(7,1)$ & $5(71,4)$ & $2(100)$ & $5(83,3)$ & $14(60,9)$ & $9(90)$ & $4(19)$ & $2(66,6)$ \\
\hline Heparín & $10(11,6)$ & $0(0)$ & $1(14,3)$ & $0(0)$ & $1(16,7)$ & $7(30,4)$ & $0(0)$ & $0(0)$ & $1(33,3)$ \\
\hline Segaleysandi & $32(37,2)$ & $0(0)$ & $0(0)$ & $2(100)$ & $4(66,7)$ & $14(60,9)$ & $9(90)$ & $0(0)$ & $3(100)$ \\
\hline Beta-hemlar & $22(25,6)$ & $1(7,1)$ & $1(14,3)$ & $1(50)$ & $1(16,7)$ & $10(43,3)$ & $4(40)$ & $3(14,3)$ & $1(33,3)$ \\
\hline Súrefni & $56(65,1)$ & $8(57,1)$ & $2(28,6)$ & $1(50)$ & $3(50)$ & $19(82,6)$ & $7(70)$ & $14(66,7)$ & $2(66,6)$ \\
\hline Morfín & $62(72,1)$ & $6(42,9)$ & $5(71,4)$ & $1(50)$ & $4(66,7)$ & $17(73,9)$ & $8(80)$ & $19(90,5)$ & $2(66,6)$ \\
\hline Nitróglycerín & $55(64)$ & $9(64,3)$ & $3(42,9)$ & $1(50)$ & $3(50)$ & $12(52,2)$ & $7(70)$ & $17(81)$ & $3(100)$ \\
\hline
\end{tabular}


Tafla III. Samanburður milli landsvæða á tíma (miðgildi) frá FSH að belgvíkkun hjá sjúklingum með STEMI í héraði sem gengust undir bráđa kransæðavíkkun og fjöldi sjúklinga par sem tíminn var undir 120 mínútum.

\begin{tabular}{lcc}
\hline & $\begin{array}{c}\text { Tími frá FSH að belgvíkkun } \\
\text { (klukkustundir) }\end{array}$ & $\begin{array}{c}\text { Fjöldi } \\
<120 \text { minútur (\%) }\end{array}$ \\
\hline Reykjanes $\mathrm{n}=10$ & $2: 06(1: 23-3: 17)$ & $5(50)$ \\
\hline Vesturland $\mathrm{n}=7$ & $3: 04(1: 27-4: 07)$ & $2(28,6)$ \\
\hline Suðurland $\mathrm{n}=17$ & $2: 46(1: 37-4: 59)$ & $2(11,8)$ \\
\hline Suðursvæði $\mathrm{n}=34$ & $2: 37(1: 23-4: 59)$ & $9(26,4)$ \\
\hline Norðursvæði $\mathrm{n}=9$ & $4: 19(3: 00-5: 44)$ & $0(0)$
\end{tabular}

Af peim sjúklingum sem fengu segaleysandi meðferð voru 13 sjúklingar (40\%) með viðvarandi ST-hækkanir við komu á Hringbraut og undirgengust pví björgunarvíkkun, að miðgildi einum klukkutíma og 19 mínútum eftir komu á Hringbraut. Fimmtán (46,9\%) sjúklingar fóru í seinkaða kransæðapræðingu að miðgildi 6 klukkustundum og 48 mínútum eftir komu á Hringbraut.

Afdrif

Af 112 sjúklingum létust 8 (7,1\%) sjúklingar innan 30 daga, 6 (5,4\%) voru endurlífgaðir í legu og 16 (14,2\%) voru lagðir inn á gjörgæsludeild. Fimm $(4,5 \%)$ sjúklingar fóru í kransæðahjáveituaðgerð innan 30 daga og einn $(0,9 \%)$ fór í ósæðarlokuskipti. Meðallegutími á Landspítala var 6 dagar, sjá töflu IV. Enginn marktækur munur var á afdrifum milli norður- og suðursvæðis.

\section{Umræður}

\section{Samantekt}

Meginviðfangsefni pessarar rannsóknar var að kanna hvort meðferð sjúklinga með brátt hjartadrep með ST-hækkunum utan höfuðborgarsvæðisins samræmdist klínískum leiðbeiningum með tilliti til flutningstíma og hvort meðferð á norðursvæði hafi breyst tveimur árum eftir að niðurstöður gæðarannsóknar voru kynntar. ${ }^{2,4}$

Flutningstími á suðursvæði var marktækt styttri en á norðursvæði en engu að síður komust einungis 9 sjúklingar (21\%) af svæðinu í kransæðavíkkun innan 120 mínútna, flestir úr byggðakjörnum næst Reykjavík. Prátt fyrir pað fékk enginn sjúklingur segaleysandi lyf og meðferð með blóðflöguhemjandi og blóðpynnandi lyfjum var ábótavant ef miðað er við klínískar leiðbeiningar frá evrópsku hjartalæknasamtökunum. ${ }^{2,3}$ Hins vegar fengu langflestir sjúklingar á norðursvæði meðferð samkvæmt klínískum leiðbeiningum prátt fyrir að tími að segaleysandi meðferð hafi lengst. Tæplega fjórðungur sjúklinga sem voru með stað-

Tafla IV. Fjöldi atvika á fyrstu 30 dögum frá innlögn (\%).

\begin{tabular}{ll}
\hline Innritast á gjörgæsludeild & $16(14,2)$ \\
\hline Látnir & $8(7,1)$ \\
\hline Endurlífgun & $6(5,4)$ \\
\hline Hjartaaðgerð & $6(5,4)$ \\
\hline Önnur hjartapræðing & $8(7,1)$ \\
\hline Ósæðarbelgspumpa & $3(2,7)$ \\
\hline Gangráðsísetning & $1(0,9)$ \\
\hline Bjargráðsísetning & $1(0,9)$ \\
\hline
\end{tabular}

festa greiningu í héraði og purftu að gangast undir bráða kransæðapræðingu eða björgunarvíkkun stoppuðu fyrst á Landspítala í Fossvogi, með tilheyrandi töfum, á leið sinni til hjartapræðingarstofu á Landspítala við Hringbraut.

\section{STEMI á landsbyggðinni og skipulag brádapjónustu}

Sameiginlegt markmið allra sem koma að meðferð sjúklinga með STEMI er að sjá til pess að stífluð kransæð sé opnuð og að súrefnisríkt blóð flæði um hjartað að nýju. Að jafnaði líða um ein til tvær klukkustundir par til einstaklingar óska eftir aðstoð vegna einkenna frá blóðpurrð í hjarta. Sjúkraflutningamenn í einhverjum af 65 sjúkrabílum utan höfuðborgarsvæðisins eru í flestum tilvikum fyrstir á staðinn og eiga allir að hafa pjálfun í að taka hjartalínurit innan 10 mínútna frá komu. Nú er nýlokið vinnu við að tengja öll Lifepak-tæki við Lifenet-kerfið hjá Physiocontrol, sem mun auðvelda rafræna sendingu á hjartalínuritum beint á Landspítala. Petta mikilvæga skref mun vonandi flýta greiningu og ekki síst aðstoða sjúkraflutningamenn og lækna á landsbyggðinni pegar greining er óljós, sem reyndist vera í 13 tilfella (11,6\%) í okkar rannsókn.

Læknir í héraði staðfestir greiningu og er ábyrgur fyrir meðferð og flutningi. Allir sjúklingar eiga að fá acetýlsalisýlsýru, klópídógrel og enoxaparín nema frábendingar séu til staðar. Alla sjúklinga með STEMI skal flytja með hraði á Landspítala. Hér er pekking á áætluðum flutningstíma nauðsynleg. Mögulegt er að opna kransæð mun fyrr ef gefið er segaleysandi lyf í héraði (mynd 5). Ef við áætlum að greining taki 10 mínútur að meðaltali og tími frá komu að Landspítala að víkkun á kransæð er að meðaltali 50 mínútur, er ljóst að flutningstíminn má ekki vera lengri en 60 mínútur. Staðsetja parf segaleysandi lyf á heilbrigðisstofnunum á landsbyggðinni með taktískum hætti svo flestir eigi möguleika á meðferð í tæka tíð. Sjúkrapyrla gæti mögulega stytt flutningstíma pegar fjarlægð að sjúkrahúsi er 60-150 kílómetrar, sem gæti haft verulega pýðingu á suðvesturhorni Íslands. ${ }^{6}$ Tilkynna parf sjúkling með STEMI sem fyrst á bráðamóttöku Landspítala pannig að hægt sé að ræsa út starfsfólk hjartapræðingarstofu og beina sjúkrabíl pá strax á Hringbraut pannig að unnt sé að framkvæma kransæðavíkkun eins fljótt og hægt er.

\section{Rétt meðferð á réttum tíma}

Sýnt hefur verið fram á kláran ávinning af blóðflöguhemjandi meðferð með acetýlsalcílsýru og klópídógreli við bráðu hartadrepi með ST-hækkunum og gefa skal lyfin eins hratt og hægt er eftir að greining hefur verið staðfest., ${ }^{3,-11}$ Hins vegar er rétt að benda á að klópídógrel hefur ekki áhrif á samloðun blóðflagna fyrr en klukkustundum eftir inntöku og lyfhrif geta verið mjög breytileg milli einstaklinga. Á síðustu árum hafa komið fram nýrri og öflugri P2Y12-hemjarar (ticagrelor, prasugrel) sem byrjað er að nota samhliða bráðri kransæðavíkkun en ekki hefur verið sýnt fram á kláran ávinning umfram klópíógrel pegar lyfið er gefið utan spítala og engar rannsóknir styðja notkun peirra samhliða segaleysandi meðferð. ${ }^{10,12,13}$

Klínískar leiðbeiningar á Íslandi hafa hingað til ekki mælt með gjöf enoxaparíns ef sjúklingur á pess kost að fara tafarlaust í bráða 


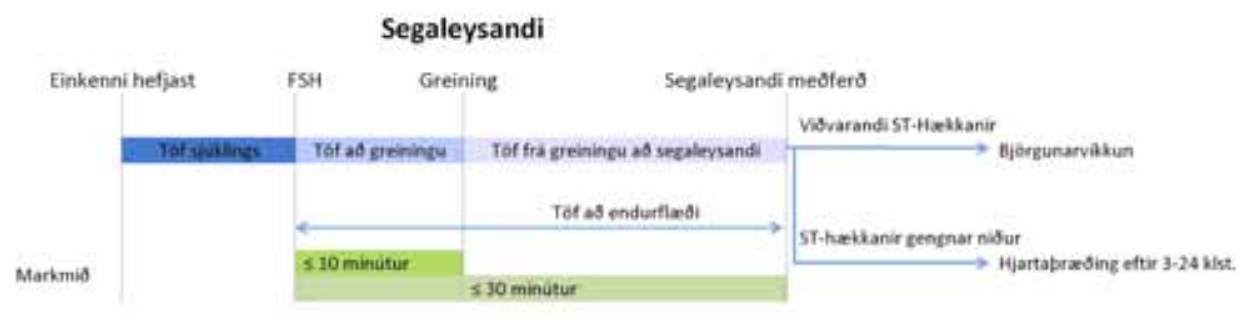

\section{Bráo hjartapræđōing}

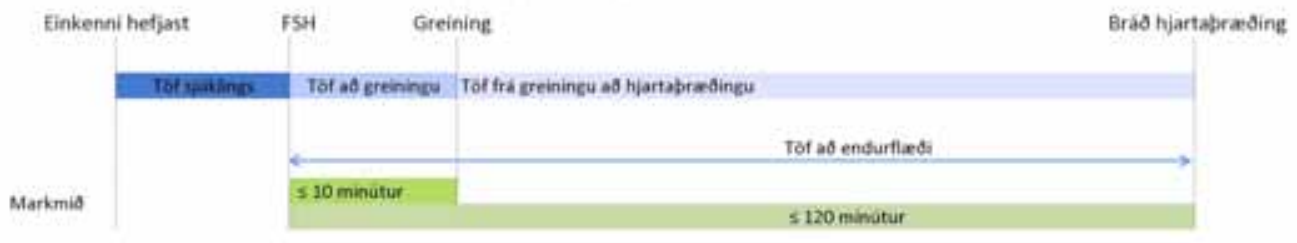

\begin{abstract}
Mynd 5. Flæðirit og tímalína sjúklinga með STEMI eftir poí hvaða meðferð er veitt. Skipulag heilbrigðispjónustu verður að tryggja að sem flestir sjúklingar fái rétta meðferð i tæka tíð pannig að töf að endurflæði verði sem styst.
\end{abstract}

kransæðavíkkun pví pað er talið trufla skömmtun blóðpynningar með heparíni í præðingunni. ${ }^{14}$ Rannsóknir hafa hins vegar sýnt fram á lægri dánartíðni og/eða minni blæðingarhættu ef enoxaparín er gefið fyrir bráða kransæðavíkkun eða samhliða gjöf segaleysandi lyfja og pví ætti ekkert að vera pví til fyrirstöðu að gefa enoxaparín í héraði. ${ }^{15}$

Pað er vel að nánast allir sjúklingar með STEMI utan höfuðborgarsvæðisins fengu acetýlsalcýlsýru og á norðursvæði fengu langflestir sjúklingar klópídógrel og enoxaparín. Á öllu suðursvæði fengu einungis tæplega 30\% sjúklinga klópídógrel og enoxaparín, par af tæplega 10\% klópídógrel á suðurlandi og 7\% enoxaparín á Reykjanesi sem verður að teljast áhyggjuefni með tilliti til klínískra leiðbeininga. ${ }^{2,3}$

Bráð kransæðavíkkun er kjörmeðferð í STEMI en klínískar leiðbeiningar eru skýrar pegar kemur að meðferð með segaleysandi lyfjum. ${ }^{16,17}$ Ef ekki er unnt að framkvæma kransæðavíkkun innan 120 mínútna frá fyrstu samskiptum við heilbrigðisstarfsmann sem er fær um að taka hjartalínurit skal gefa segaleysandi lyf. Hjá yngri einstaklingum (<65 ára) með framveggsdrep, sem voru 18 talsins í okkar úrtaki, er ráđlagt að pessi tími sé ekki lengri en 90 mínútur. ${ }^{2,3}$ Gjöf segaleysandi lyfja utan spítala pykir örugg, lífslíkur aukast eftir pví sem meðferð er hafin fyrr og árangur er mestur pegar sjúklingur hefur haft einkenni í stuttan tíma. ${ }^{18-20}$

Í nýlegri erlendri rannsókn (STREAM - Strategic Reperfusion Early After Myocardial Infarction) reyndist segaleysandi meðferð jafngild bráðri kransæðavíkkun að teknu tilliti til dánartíðni, losts, hjartabilunar og líkinda á öðru hjartadrepi innan 30 daga (12,4\% á móti 14,3\%; p=0,21) ef ljóst pótti að ekki væri hægt að framkvæma kransæðavíkkun innan 60 mínútna og að viðkomandi hafði haft einkenni skemur en prjár klukkustundir. ${ }^{21}$ Sjúklingar sem fengu segaleysandi meðferð fengu hana að meðaltali 100 mínútum eftir að einkenni hófust og að meðaltali 78 mínútum fyrr en peir sem gengust undir bráða kransæðavíkkun. Tíðni hjartabilunar og losts var marktækt lægri í hópnum sem fékk segaleysandi meðferð en ekki var marktækur munur á tíðni heilablæðinga eftir að tenecteplase-skammturinn var helmingaður hjá sjúklingum eldri en 75 ára.
Í okkar rannsókn fengu rétt tæplega prír af hverjum fjórum sjúklingum á norðursvæði segaleysandi meðferð að miðgildi 57 mínútum eftir FSH, fjórðungur hafði frábendingu skráða í sjúkraskrá en einungis einn sjúklingur fékk ekki segaleysandi meðferð án pess að ástæðu væri getið. Enginn sjúklingur í okkar úrtaki hlaut fylgikvilla eftir segaleysandi meðferð. Tími frá FSH að segaleysandi meðferð hefur aukist um 24 mínútur borið saman við rannsókn okkar 2010, sem við höfum ekki viðhlítandi skýringu á og verður pað að teljast áhyggjuefni. Borið saman við fyrri rannsókn hefur fjöldi sjúklinga sem fær rétta meðferð miðað við skráningu í sjúkraskrá aukist verulega (97 á móti 58\%). ${ }^{4}$

Stór hluti sjúklinga sem fengu segaleysandi meðferð var enn með ST-hækkanir við komu á Landspítala og fór í björgunarvíkkun sem var framkvæmd að miðgildi einum klukkutíma og 19 mínútum eftir komu á Hringbraut (dreifing 0:22 - 2:02 klst.). Petta er heldur lengri tími (79 á móti 45 mín) en svipað hlutfall (40 á móti 37,5\%) borið saman við fyrri rannsókn okkar, en heldur hærra hlutfall en í erlendum rannsóknum., ${ }^{421,22}$

Á suðursvæði Íslands fóru allir sjúklingar nema tveir (sem höfðu haft einkenni lengi) í bráða kransæðapræðingu að miðgildi 50 mínútum eftir komu á Landspítala. Kransæð var víkkuð og opnuð hjá 34 sjúklingum að miðgildi tveimur klukkustundum og 37 mínútum frá FSH en einungis í 9 tilfellum innan 120 mínútna. Par af voru 5 sjúklingar af Reykjanesi (50\%) sem liggur næst Reykjavík en einungis tveir sjúklingar af Suðurlandi (10\%) og tveir af Vesturlandi (29\%). Um pað bil prír af hverjum fjórum sjúklingum á öllu suðursvæði fengu pví ekki meðferð samkvæmt klínískum leiðbeiningum. Af peim 25 sjúklingum sem komust ekki í kransæðavíkkun fyrr en liðnar voru meira en 120 mínútur frá FSH höfðu 15 haft einkenni skemur en prjár klukkustundir.

Nítján sjúklingar höfðu að ástæðulausu viðkomu í Fossvogi á leið sinni á præðingarstofu á Hringbraut sem er í rúmlega priggja kílómetra fjarlægð. Petta orsakaði tafir á meðferð að miðgildi 25 mínútur sem er stuttur tími í alpjóðlegum samanburði. ${ }^{23}$ I fjórum tilfellum pótti ástæða til að skrá í sjúkraskrá að ekki hafi verið búið að kalla út starfsfólk præðingarstofu fyrir komu í Fossvog og í einu tilfelli var sjúklingur í alvarlegu lostástandi og purfti öndunaraðstoð og pví ekki hægt að flytja hann strax. Рað sem er 
athugunarvert er að útkallstími starfsfólks á præðingarstofu er í öllum tilfellum styttri en flutningstími úr héraði beint á Hringbraut og pví ætti ekki að vera nein ástæða fyrir pví að koma við í Fossvogi nema í undantekningartilvikum.

\section{Afdrif í legu}

Legutími á Landspítalanum var að meðaltali 6 dagar, sem er sambærilegt við fyrri rannsókn. Dánartíðni innan 30 daga var 7,1\% sem er nokkru hærra en í STREAM-rannsókninni $(4,5 \%){ }^{21}$ Á alpjóðavísu mælist dánarhlutfall vegna STEMI innan 30 daga á bilinu 4,2-13,5\%. ${ }^{24}$ Enginn marktækur munur var á dánartíðni, innlögn á gjörgæslu, endurlífgun eða opinni hjartaaðgerð milli sjúklinga sem fluttir voru frá norður- eða suðursvæði.

\section{STEMI og gæðaeftirlit}

Gæðaeftirlit er augljós krafa í nútímaheilbrigðiskerfi. Klínískar leiðbeiningar fyrir STEMI eru vel skilgreindar, með skýrum markmiðum og innihalda breytur sem auðvelt er að mæla og geta skipt miklu máli fyrir afdrif sjúklingsins. Rannsókn okkar sem birtist í Læknablaðinu árið 2010 er í raun fyrsta gæðarannsókn á sjúklingum með STEMI frá upphafi einkenna og að útskrift af sjúkrahúsi og sýndi fram á bresti í meðferð sjúklinga með STEMI á norðursvæði Íslands. Flutningstími var lengri en talið var og meðferð með segaleysandi lyfjum ábótavant. Niðurstöður voru kynntar á norðursvæði og á Læknadögum 2010 og áhersla lögð á að klínískum leiðbeiningum væri fylgt. Pað er pví afar ánægjulegt að sjá í pessari rannsókn pá jákvæðu próun sem orðið hefur á meðferð sjúklinga með STEMI á norðursvæðinu.

Раð einkennir hins vegar báðar pessar rannsóknir hversu tímafrekt er að nálgast og skrá handvirkt mikilvægar breytur par sem tölvukerfi eru ekki samtengd og í einstaka tilfellum eru gögnin eingöngu skráð á pappír. Sjúklingar með STEMI sem gangast undir kransæðapræðingu í Svípjóð eru skráðir í SCAAR-gagnagrunninn (Svenska Coronär Angiografi- och Angioplastik Registret) sem haldið er úti af Klíníska Rannsóknarsetrinu í Uppsölum (Uppsala Clinical Research Center). ${ }^{25}$ Sænski gagnagrunnurinn skráir hins vegar ekki mikilvægar breytur, svo sem tíma frá FSH að endurflæðismeðferð og tekur ekki tillit til staðbundinna pátta sem eru mikilvægir pegar heildarmyndin er skoðuð. Раð er pví nauðsynlegt að koma á laggirnar íslenskum gagnagrunni fyrir sjúklinga með STEMI sem nær til alls landsins. Petta myndi gera heilbrigðisyfirvöldum kleift að mæla áhrif af kerfislægum breytingum (til dæmis innleiðingu LifePort-kerfis) og gera heilbrigðisstofnunum um allt land kleift að setja sér raunhæf markmið (til dæmis $>90 \%$ fylgni við klínískar leiðbeiningar) og fylgja peim eftir með kerfisbundnum hætti.

\section{Ályktun og úrbætur}

Meðferð við STEMI á norðursvæði á árunum 2011-2012 var í stórauknu samræmi við alpjóðlegar klínískar leiðbeiningar borið saman við árin 2007-2008. Petta staðfestir að gæðarannsóknir á meðferð við STEMI skipta máli og geta haft jákvæð áhrif á pjónustuna séu pær kynntar vel.

Á suðursvæði má sjá sama mynstur og sást á norðursvæði á árunum 2007-2008. Flutningstíminn er vanmetinn og meðferð ekki í samræmi við gildandi leiðbeiningar. Verði sendingarbúnaði komið fyrir í öllum sjúkrabílum landsins verður hægt að senda hjartalínurit beint á Landspítala. Pá opnast möguleiki á að flýta og betrumbæta túlkun á hjartalínuriti og par með skipuleggja meðferð og flutning með peim hætti að fleiri sjúklingar eigi möguleika á kransæðavíkkun innan 120 mínútna. Sjúkraflutningamenn og læknar í héraði gegna par lykilhlutverki. Full ástæða er til að útbúa staðfærðar klínískar leiðbeiningar í hverjum landshluta sem taka mið af nýjum upplýsingum. Sjúklinga með STEMI á suðursvæði ætti til dæmis ekki að flytja á aðra heilbrigðisstofnun en Landspítala Hringbraut nema í undantekningartilvikum. ${ }^{1,26}$ Skoða parf hvort forsendur séu fyrir pví að koma á fót sérstakri sjúkrapyrlu með bundinni vakt eða hvort hægt sé að stytta viðbragðstíma pyrlusveitar Landhelgisgæslunnar, til dæmis með staðarvakt í stað bakvaktar og auka hlutverk hennar í sjúkraflutningum á suðvesturhorninu. Pá parf að athuga vel hvort ástæða sé til að fjölga lyfjaskömmtum á svæðum fjær Reykjavík. Íhuga ætti sterklega segaleysandi meðferð hjá ungum einstaklingum (<65 ára) með upphaf einkenna innan priggja tíma og greinilegar ST-hækkanir í framvegg eða nýtilkomið vinstra greinrof og týpísk einkenni, búsettum í byggðakjörnum næst höfuðborgarsvæðinu, svo sem Akranesi, Keflavík og Selfossi.

\section{Styrkur og takmörkun rannsóknar}

Helsti styrkur pessarar rannsóknar er að hún lýsir vel peirri meðferð sem sjúklingar utan höfuðborgarsvæðisins með brátt hjartadrep fengu á árunum 2011-2012, hversu langan tíma tekur að flytja pá á sjúkrahús til kransæðavíkkunar og hvort klínískum leiðbeiningum hafi verið fylgt. Rannsóknin hefur einnig ýmsar takmarkanir. Hún gerir ekki grein fyrir sjúklingum sem dóu úr STEMI fyrir komu á heilbrigðisstofnun eða peim sem hugsanlega voru ekki fluttir á Landspítala til frekari meðferðar. Pví má áætla að nýgengi sé í raun hærra en hér er sýnt. Rannsóknin er afturskyggn og ekki nægjanlega fjölmenn til að greina mun á afdrifum eftir meðferð. Upplýsingarnar eru takmarkaðar við pað sem skráð var í sjúkraskrám viðkomandi á Landspítala, í sjúkraflutningi og peirri heilbrigðisstofnun sem óskaði eftir flutningi.

\section{Pakkir}

Pakkir fá Eyrún Franzdóttir ritari hjartadeildar Landspítala á Hringbraut, ritarar lyfjadeildar og bráđadeildar Sjúkrahússins á Akureyri, Pálmi Óskarsson læknir á bráđadeild Sjúkrahússins á Akureyri og Garðar Guðmundsson hjá Neyðarlínunni.

Rannsóknin var styrkt að upphæð 300.000 krónur af samfélagssjóði Samherja. 


\section{Heimildir}

1. Terkelsen CJ, Sorensen JT, Maeng M, Jensen LO, Tilsted $\mathrm{HH}$, Trautner S, et al. System delay and mortality among patients with STEMI treated with primary percutaneous coronary intervention. JAMA 2010; 304: 763-71.

2. Van de Werf F, Bax J, Betriu A, Blomstrom-Lundqvist C, Crea F, Falk V, et al. Management of acute myocardial infarction in patients presenting with persistent ST-segment elevation: the Task Force on the Management of ST-Segment Elevation Acute Myocardial Infarction of the European Society of Cardiology. Eur Heart J 2008; 29: 2909-45.

3. Steg PG, James SK, Atar D, Badano LP, BlomstromLundqvist C, Borger MA, et al. ESC Guidelines for the management of acute myocardial infarction in patients presenting with ST-segment elevation. Eur Heart J 2012; 33: 2569-619.

4. Sigmundsson TS, Gunnarsson B, Benediktsson S, Gunnarsson GT, Duason S, Thorgeirsson G. Flutningstími og gæði meðferðar hjá sjúklingum með ST-hækkunar hjartadrep á Norður- og Austurlandi. Læknablaðið 2010; 96: 159-65.

5. Thygesen K, Alpert JS, White HD. Universal definition of myocardial infarction. J Am Coll Cardiol 2007; 50: 2173-95.

6. Knudsen L, Stengaard C, Hansen TM, Lassen JF, Terkelsen CJ. Earlier reperfusion in patients with ST-elevation myocardial infarction by use of helicopter. Scand J Trauma Resusc Emerg Med 2012; 20: 70

7. Baigent C, Collins R, Appleby P, Parish S, Sleight P, Peto R. ISIS-2: 10 year survival among patients with suspected acute myocardial infarction in randomised comparison of intravenous streptokinase, oral aspirin, both, or neither. The ISIS-2 (Second International Study of Infarct Survival) Collaborative Group. BMJ 1998; 316: 1337-43.

8. Sabatine MS, Cannon CP, Gibson CM, Lopez-Sendon JL Montalescot G, Theroux P, et al. Addition of clopidogrel to aspirin and fibrinolytic therapy for myocardial infarction with ST-segment elevation. N Engl J Med 2005; 352: 117989.

9. Chen ZM, Jiang LX, Chen YP, Xie JX, Pan HC, Peto R, et al. Addition of clopidogrel to aspirin in 45,852 patients with acute myocardial infarction: randomised placebocontrolled trial. Lancet 2005; 366: 1607-21.
10. Huber K, Bates ER, Valgimigli M, Wallentin L, Kristensen $\mathrm{SD}$, Anderson JL, et al. Antiplatelet and anticoagulation agents in acute coronary syndromes: What is the current status and what does the future hold? Am Heart J 2014; 168: 611-21.

11. Verheugt FW, Montalescot G Sabatine MS, Soulat L Lambert Y, Lapostolle F, et al. Prehospital fibrinolysis with dual antiplatelet therapy in ST-elevation acute myocardial infarction: a substudy of the randomized double blind CLARITY-TIMI 28 trial. J Thromb Thrombolysis 2007; 23: 173-9.

2. Montalescot G, van 't Hof AW, Lapostolle F, Silvain J, Lassen JF, Bolognese L, et al. Prehospital ticagrelor in ST-segment elevation myocardial infarction. N Engl J Med 2014; 371: 1016-27.

13. Alexopoulos D, Xanthopoulou I, Goudevenos J. Effects of P2Y12 receptor inhibition in patients with ST-segment elevation myocardial infarction. Am J Cardiol 2014; 113: 2064-9.

14. Arnar DO. Klínískar leiðbeiningar um greiningu og meðferð sjúklinga með brjóstverk. 2009. landspitali.is/lisalib/ getfile.aspx?itemid=19460. - desember 2015

15. Sabatine MS, Morrow DA, Montalescot G, Dellborg M, Leiva-Pons JL, Keltai M, et al. Angiographic and clinical outcomes in patients receiving low-molecular-weight heparin versus unfractionated heparin in ST-elevation myocardial infarction treated with fibrinolytics in the CLARITY-TIMI 28 Trial. Circulation 2005; 112: 3846-54

16. Grines C, Patel A, Zijlstra F, Weaver WD, Granger C, Simes RJ. Primary coronary angioplasty compared with intravenous thrombolytic therapy for acute myocardial infarction: six-month follow up and analysis of individual patient data from randomized trials. Am Heart J 2003; 145: 47-57.

7. Keeley EC, Boura JA, Grines CL. Primary angioplasty versus intravenous thrombolytic therapy for acute myocardial infarction: a quantitative review of 23 randomised trials. Lancet 2003; 361: 13-20.

18. Morrison LJ, Verbeek PR, McDonald AC, Sawadsky BV, Cook DJ. Mortality and prehospital thrombolysis for acute myocardial infarction: A meta-analysis. JAMA 2000; 283: $2686-92$.
19. Bjorklund E, Stenestrand U, Lindback J, Svensson L, Wallentin L, Lindahl B. Pre-hospital thrombolysis delivered by paramedics is associated with reduced time delay and mortality in ambulance-transported real-life patients with ST-elevation myocardial infarction. Eur Heart J 2006; 27: 1146-52.

20. Danchin N, Blanchard D, Steg PG, Sauval P, Hanania G, Goldstein P, et al. Impact of prehospital thrombolysis for acute myocardial infarction on 1-year outcome: results from the French Nationwide USIC 2000 Registry. Circulation 2004; 110: 1909-15.

21. Armstrong PW, Gershlick AH, Goldstein P, Wilcox R, Danays T, Lambert $Y$, et al. Fibrinolysis or primary PCI in ST-segment elevation myocardial infarction. N Engl J Med 2013; 368: 1379-87.

22. Bonnefoy E, Lapostolle F, Leizorovicz A, Steg G, McFadden EP, Dubien PY, et al. Primary angioplasty versus prehospital fibrinolysis in acute myocardial infarction: a randomised study. Lancet 2002; 360: 825-9.

23. Miedema MD, Newell MC, Duval $S$, Garberich RF, Handran CB, Larson DM, et al. Causes of delay and associated mortality in patients transferred with ST-segmentelevation myocardial infarction. Circulation 2011; 124: $1636-44$

24. Widimsky P, Wijns W, Fajadet J, de Belder M, Knot J, Aaberge L, et al. Reperfusion therapy for ST elevation acute myocardial infarction in Europe: description of the current situation in 30 countries. Eur Heart J 2010; 31: 94357.

25. ucr.uu.se/swedeheart/index.php/start-scaar - september 2015

26. Steg PG, Cambou JP, Goldstein P, Durand E, Sauval P, Kadri Z, et al. Bypassing the emergency room reduces delays and mortality in ST elevation myocardial infarction: the USIC 2000 registry. Heart 2006; 92: 1378-83.

\title{
ENGLISH SUMMARY
}

\section{Transport and treatment of patients with STEMI in rural Iceland - Only a few patients receive $\mathrm{PPCI}$ within 120 minutes}

\begin{abstract}
Sigmundsson TS ${ }^{1}$, Arnarson D², Rafnsson $A^{3}$, Magnusson V, Gunnarsson GT ${ }^{2,5}$, Thorgeirsson G
\end{abstract}
Introduction: ST-segment Elevation Myocardial Infarction (STEMI) is a life-threatening disease and good outcome depends on early restoration of coronary blood flow. Primary percutaneous coronary intervention (PPCI) is the treatment of choice if performed within 120 minutes of first medical contact (FMC) but in case of anticipated long transport or delays, pre-hospital fibrinolysis is indicated. The aim was to study transport times and adherence to clinical guidelines in patients with STEMI transported from outside of the Reykjavik area to Landspitali University Hospital in Iceland.

Materials and methods: Retrospective chart review was conducted of all patients diagnosed with STEMI outside of the Reykjavik area and transported to Landspitali University Hospital in Reykjavik in 2011-2012. Descriptive statistical analysis and hypothesis testing was applied. Results: Eighty-six patients had signs of STEMI on electrocardiogram (ECG) at FMC. In southern Iceland nine patients (21\%) underwent
$\mathrm{PPCl}$ within 120 minutes (median 157 minutes) and no patient received fibrinolysis. In northern Iceland and The Vestman Islands, where long transport times are expected, $96 \%$ of patients eligible for fibrinolysis $(n=31)$ received appropriate therapy in a median time of 57 minutes. Significantly fewer patients received appropriate anticoagulation treatment with clopidogrel and enoxaparin in southern Iceland compared to the northern part. Mortality rate was $7 \%$ and median length of stay in hospital was 6 days.

Conclusions: Time from FMC to PPCl is longer than 120 minutes in the majority of cases. Pre-hospital fibrinolysis should be considered as first line treatment in all parts of Iceland outside of the Reykjavik area. Directly electronically transmitted ECGs and contact with cardiologist could hasten diagnosis and decrease risk of unnecessary interhospital transfer. A STEMI database should be established in Iceland to facilitate quality control.

'Department of Anaesthesiology, Surgical Services and Intensive Care Medicine, Karolinska University Hospital, Sweden, ${ }^{2}$ Faculty of Medicine University of Iceland, ${ }^{3}$ Dept. of anaesthetics and intensive care I Landspitalinn University Hospital Reykjavik, ${ }^{4}$ Dept. of Cardiology, ${ }^{5}$ Akureyri Hospital, Iceland.

Key words: STEMI, fibrinolysis, quality of care, medical transport, rural medicine.

Correspondence: Pórir Sigmundsson, thorir.sigmundsson@karolinska.se 